\title{
A review of body mass index and waist circumference as markers of obesity and coronary heart disease risk in persons with chronic spinal cord injury
}

\author{
AC Buchholz*,1 and JM Bugaresti ${ }^{2}$ \\ ${ }^{1}$ Department of Family Relations and Applied Nutrition, University of Guelph, Guelph, Ontario, Canada; \\ ${ }^{2}$ Department of Medicine, McMaster University, Hamilton, Ontario, Canada
}

\begin{abstract}
Study design: Literature review.
Background: Increased fat mass and coronary heart disease (CHD) are secondary complications of chronic spinal cord injury (SCI). In able-bodied populations, body mass index (BMI, body weight $(\mathrm{kg}) /$ height $\left(\mathrm{m}^{2}\right)$ ) is a widely used surrogate marker of obesity and predictor of CHD risk. Waist circumference, an accurate and reproducible surrogate measure of abdominal visceral adipose tissue, is also associated with CHD risk (more so than BMI) in able-bodied populations.

Objective: To review the literature on the accuracy of BMI and waist circumference as surrogate measures of obesity and CHD risk in persons with chronic SCI.

Setting: Ontario, Canada.

Methods: Literature review.

Results: In the SCI population, BMI is an insensitive marker of obesity, explains less of the variance in measured percent fat mass than in the able-bodied, and is inconsistently related to $\mathrm{CHD}$ risk factors. This may be due to potential measurement error, and to the inability of BMI to distinguish between fat and fat-free mass and to measure body fat distribution. Waist circumference has not been validated as a surrogate measure of visceral adipose tissue, however preliminary evidence supports a relationship between waist circumference and CHD risk in the SCI population.

Conclusions: We recommend that SCI-specific BMI classifications be determined. We also recommend that accuracy and reliability of waist circumference as a surrogate measure of visceral adipose tissue and CHD risk be determined in men and women with long-standing paraplegia and tetraplegia.

Spinal Cord (2005) 43, 513-518. doi:10.1038/sj.sc.3101744; published online 12 April 2005
\end{abstract}

Keywords: body mass index; body composition; obesity; waist circumference; coronary heart disease; spinal cord injury

\section{Body mass index (BMI) as a marker of obesity in chronic SCI}

Obesity is defined as an excess accumulation of fat mass. Able-bodied men and women $\leqslant 40$ years are considered obese when fat mass exceeds $22-25$ and $35 \%$ of body weight, respectively. ${ }^{1,2}$ As individuals age, fat mass accrues at the expense of fat-free mass, so that at older ages percentage fat mass is higher, even in individuals who do not gain weight. ${ }^{3}$ Thus, obesity in 41-60-yearold able-bodied men and women can be defined as a fat mass $>25$ and $>38 \%$ of body weight, respectively. ${ }^{2}$ Mean percent fat mass (measured by dual energy X-ray

*Correspondence: AC Buchholz, Department of Family Relations and Applied Nutrition, University of Guelph, Guelph, Ontario, Canada N1G 2W1 absorptiometry (DXA), isotope dilution or the threecompartment model) reported in cross-sectional studies of persons (mostly men) with chronic spinal cord injury (SCI) ranges from 23 to $35 \% .^{4-11}$ The percentage of body weight as fat mass is $8-18 \%$ higher in SCI versus age-, height- and/or weight-matched able-bodied control subjects. These values are often consistent with the above definitions of obesity, and are summarized in Table 1.

Accurate classification of an individual as normal weight, overweight or obese requires measurement of body composition. However, measuring fat mass can be difficult and expensive, and no accurate method is easily available for routine clinical use. Therefore, the body mass index (BMI) is widely used. Expressed as weight $(\mathrm{kg})$ divided by height $\left(\mathrm{m}^{2}\right)$, BMI allows classification of able-bodied adults as underweight, normal weight, 
Table 1 BMI and measured percent fat mass in cross-sectional studies of adults with chronic spinal cord injury

\begin{tabular}{|c|c|c|c|c|}
\hline Reference & Study population $(s)$ & $\begin{array}{l}\text { Body composition } \\
\text { method }\end{array}$ & $B M I\left(\mathrm{~kg} / \mathrm{m}^{2}\right)$ & Percent fat mass \\
\hline $\begin{array}{l}\text { Modlesky et al, } \\
2004^{9}\end{array}$ & $\begin{array}{l}\text { Eight men with complete SCI } \\
\text { (tetraplegic and paraplegic), } 35 \pm 9^{\text {a }} \\
\text { years, duration postinjury not reported; } \\
\text { eight age-, height- and weight-matched } \\
\text { able-bodied male controls }\end{array}$ & $\mathrm{DXA}^{\mathrm{b}}$ & $\begin{array}{l}\text { SCI: } 24.6 \\
\text { Controls: } 25.0 \\
(P \text { not reported })\end{array}$ & $\begin{array}{l}\text { SCI: } 33.8 \pm 16.4 \\
\text { Controls: } \\
16.2 \pm 8.7 \\
(P<0.05)\end{array}$ \\
\hline $\begin{array}{l}\text { Buchholz et al, } \\
2003^{7}\end{array}$ & $\begin{array}{l}28 \text { adults with paraplegia ( } 17 \text { men, } 11 \\
\text { women; } 18 \text { complete, } 10 \text { incomplete }) \\
33.9 \pm 9.2 \text { years, } \geqslant 1.5 \text { years postinjury; } \\
34 \text { BMI-matched able-bodied controls } \\
(24 \text { men, } 10 \text { women }), 29.1 \pm 7.6 \text { years }\end{array}$ & $\begin{array}{l}\text { Deuterium } \\
\text { dilution }\end{array}$ & $\begin{array}{l}\text { Paraplegic: } \\
24.3 \pm 6.0 \\
\text { Controls: } \\
23.5 \pm 1.8 \\
(P=0.8258)\end{array}$ & $\begin{array}{l}\text { Paraplegic: } \\
30.8 \pm 8.7 \\
\text { Controls: } \\
22.8 \pm 7.2 \\
(P=0.0002)\end{array}$ \\
\hline Jeon et al, $2003^{11}$ & $\begin{array}{l}\text { Seven men with complete tetraplegia, } \\
38.3 \pm 3.1 \text { years (mean } \pm \text { SEM); seven } \\
\text { age-, weight-, height-, BMI- and waist } \\
\text { circumference-matched able-bodied } \\
\text { male controls }\end{array}$ & DXA & $\begin{array}{l}\text { SCI: } 26.7 \pm 1.5 \\
\text { Controls: } \\
29.4 \pm 1.6 \\
\text { (NS) }\end{array}$ & $\begin{array}{l}\text { SCI: } 34.6 \pm 7 \\
\text { Controls: } \\
24.4 \pm 6.5 \\
(P=0.016)\end{array}$ \\
\hline Jones et al, $2003^{6}$ & $\begin{array}{l}20 \text { men with SCI (13 tetraplegic, seven } \\
\text { paraplegic; five ASIA A, six ASIA B, } \\
\text { one ASIA C, one ASIA D), 16-52 years, } \\
\geqslant 1 \text { year postinjury; } 20 \text { age-, height- and } \\
\text { weight-matched able-bodied male } \\
\text { controls }\end{array}$ & DXA & $\begin{array}{l}\text { SCI: } 23.1 \pm 3.9 \\
\text { Controls: } \\
24.0 \pm 1.8 \\
(P=0.34)\end{array}$ & $\begin{array}{l}\text { SCI: } 27.5 \pm 10.4 \\
\text { Controls: } \\
18.1 \pm 6.5 \\
(P<0.02)\end{array}$ \\
\hline $\begin{array}{l}\text { Maggioni et al, } \\
2003^{8}\end{array}$ & $\begin{array}{l}13 \text { men with SCI (one tetraplegic, } 12 \\
\text { paraplegic), } 33.8 \pm 5.4 \text { years, } \geqslant 4 \text { years } \\
\text { postinjury; } 13 \text { age- and BMI-matched } \\
\text { able-bodied male controls }\end{array}$ & DXA & $\begin{array}{l}\text { SCI: } 25.7 \pm 4.3 \\
\text { Controls: } \\
24.5 \pm 2.4 \\
\text { (NS) }\end{array}$ & $\begin{array}{l}\text { SCI: } 31.1 \pm 8.2 \\
\text { Controls: } \\
20.8 \pm 6.9 \\
(P<0.05)\end{array}$ \\
\hline $\begin{array}{l}\text { Spungen et al, } \\
2003^{5}\end{array}$ & $\begin{array}{l}133 \text { men with SCI ( } 66 \text { tetraplegic, } 67 \\
\text { paraplegic; } 94 \text { motor complete), } \\
\text { approximately } 38-40 \text { years, } \\
\text { approximately } 11-14 \text { years postinjury } \\
\text { (group means not reported) }\end{array}$ & DXA & $\begin{array}{l}\text { Tetraplegic: } \\
25.4 \pm 0.66 \\
(\text { mean } \pm \text { SEM) } \\
\text { Paraplegic: } \\
25.8 \pm 0.56\end{array}$ & $\begin{array}{l}\text { Complete } \\
\text { tetraplegic: } 34 \pm 2 \\
\text { Incomplete } \\
\text { tetraplegic: } 35 \pm 2 \\
\text { Complete } \\
\text { paraplegic: } \\
33.1 \pm 1 \\
\text { Incomplete } \\
\text { paraplegic: } 28 \pm 3\end{array}$ \\
\hline $\begin{array}{l}\text { Desport et al, } \\
2000^{10}\end{array}$ & $\begin{array}{l}20 \text { adults with SCI (tetraplegic and } \\
\text { paraplegic; } 15 \text { men, five women), } \\
45.2 \pm 12.8 \text { years, } \geqslant 4 \text { months postinjury }\end{array}$ & $\begin{array}{l}\text { Three- } \\
\text { compartment } \\
\text { model }\left({ }^{18} \mathrm{O}\right. \\
\text { dilution, skinfold } \\
\text { thickness, weight })\end{array}$ & $26.9 \pm 4.4$ & $32.8 \pm 6.8$ \\
\hline $\begin{array}{l}\text { Monroe et al, } \\
1998^{4}\end{array}$ & $\begin{array}{l}10 \text { men with SCI (one tetraplegic, nine } \\
\text { paraplegic; all Frankel Class A), } \\
35.5 \pm 8.0 \text { years, } \geqslant 2 \text { years postinjury }\end{array}$ & DXA & 21.7 & $23 \pm 12$ \\
\hline
\end{tabular}

${ }^{\mathrm{a}}$ Mean $\pm \mathrm{SD}$, unless otherwise indicated.

${ }^{\mathrm{b}}$ Dual energy X-ray absorptiometry.

overweight or obese, using the World Health Organization criteria in Table 2. ${ }^{12}$ Mean BMI values in studies of persons with long-standing SCI range from 20 to $27,{ }^{5,6,10,13-18}$ consistent with the classifications of normal and overweight, but inconsistent with classification based on measured percent fat mass. ${ }^{4-11}$ One reason for the underestimation of obesity using BMI may be the potential measurement error associated with determination of weight and/or height in persons with SCI. While weight can be measured using a wheelchair scale, an accurate height is difficult to obtain in those who are wheelchair dependent. Ideally, height is measured with the subject standing against a stadiometer, with his/her head in the Frankfurt plane and shoulders, buttocks and heels pressed against the stadiometer. ${ }^{19}$ This may not be possible in a significant proportion of persons with SCI. Subject recall of height is not recommended as recalled height and measured length have been found to disagree, independent of age or years since injury. ${ }^{20}$ Despite this, recalled height has been used in a number of studies reporting BMI in subjects with chronic SCI. ${ }^{5,16,17}$ An alternative is to measure length. Jones et $a l^{21}$ reported the Pearson's correlation coefficient for height (measured by wall-mounted stadiometer) versus length (by the electronic ruler function of DXA) to be $0.996(P=0.0001)$. Buchholz et $a l^{22}$ found the 
Table 2 World Health Organization ${ }^{12}$ classification of adults according to the BMI

\begin{tabular}{|c|c|c|}
\hline Classification & $B M I$ & $\begin{array}{l}\text { Risk of } \\
\text { comorbidities }\end{array}$ \\
\hline Underweight & $<18.50$ & $\begin{array}{l}\text { Low (but risk of } \\
\text { other clinical } \\
\text { problems } \\
\text { increased) }\end{array}$ \\
\hline Normal range & $18.50-24.99$ & Average \\
\hline $\begin{array}{l}\text { Overweight/ } \\
\text { preobese }\end{array}$ & $25.00-29.99$ & Increased \\
\hline Obese class I & $30.00-34.99$ & Moderate \\
\hline Obese class II & $35.00-39.99$ & Severe \\
\hline Obese class III & $\geqslant 40.00$ & Very severe \\
\hline
\end{tabular}

coefficient of variation between height (by wall-mounted stadiometer) versus length (by length board) to be $0.8 \pm 0.02 \%$ (mean $\pm \mathrm{SD}$, NS). Comparisons between methods in both studies were performed on able-bodied subjects; nonetheless, these data indicate good agreement between length and stadiometer-determined height.

A second potential reason for the underestimation of obesity using BMI is that persons with chronic SCI have greater fat mass and less fat-free mass per unit BMI than age-matched able-bodied control subjects. ${ }^{6,22,23}$ Thus, despite greater fat mass in subjects with versus without SCI, body weight and BMI often do not differ. $5,6,8,9,11,22$ Buchholz et $a l^{22}$ found the $30 \mathrm{~kg} / \mathrm{m}^{2}$ BMI cutoff correctly identified only $20 \%$ of truly obese paraplegic subjects, as compared with published sensitivity values of $48-66 \%$ in able-bodied populations. ${ }^{24-26}$ In the study of Buchholz et al, weight was measured using a wheelchair scale, length was measured using a length board, fat mass was determined by isotope dilution and obesity was defined by the method of Lohman. ${ }^{2}$ Finally, BMI has been found to explain $46-79 \%$ of the variance in measured percent fat mass in able-bodied persons, $5,27-29$ compared with only $35-36 \%$ in persons with SCI. ${ }^{5,30}$

Taken together, these findings suggest that BMI is a poor surrogate marker of obesity in the chronic SCI population. The $30 \mathrm{~kg} / \mathrm{m}^{2}$ cutoff recommended by the World Health Organization to define obesity in ablebodied persons is insensitive in persons with longstanding SCI. This may be due to potential measurement error and the inability of body weight to distinguish between fat mass and fat-free mass.

\section{BMI as a marker of coronary heart disease (CHD) risk in chronic SCI}

CHD is now a major cause of morbidity and mortality in persons with SCI. ${ }^{31-33} \mathrm{~A}$ higher prevalence of $\mathrm{CHD}$ has been reported in individuals with duration of SCI greater than 10 years compared with relatively healthy age-matched controls. ${ }^{34}$ SCI is associated with a number of risk factors for CHD. High-density lipoprotein (HDL) cholesterol levels are $20-42 \%$ lower $(P<0.05)$ in persons with SCI than in able-bodied persons. ${ }^{14,15,35-37}$ Triglyceride levels are 6-60\% higher in SCI, although not always significantly so. ${ }^{15,35-38}$ Total and low-density lipoprotein (LDL) cholesterols are either higher, similar, or lower, than in able-bodied subjects, ${ }^{15,16,37,39,40}$ the relatively small number of subjects and differences in subject characteristics studied may account for these discrepancies. Impaired glucose tolerance, insulin resistance and diabetes occur more frequently in SCI versus able-bodied persons. ${ }^{15,38,41-45}$ Other potential CHD risk factors after SCI include decreased physical activity, psychosocial factors (depression, isolation), and elevated plasma homocysteine and C-reactive protein. ${ }^{46}$

Increased fat mass has also been identified as an important risk factor in chronic SCI and weight management is recommended as a key CHD prevention strategy. ${ }^{46}$ Obesity, and its surrogate BMI, is associated with many CHD risk factors in able-bodied persons, including dyslipidemia (increased LDL cholesterol and triglycerides, and increased HDL cholesterol), hyperinsulinemia, glucose intolerance and hypertension. ${ }^{4-50}$ The World Health Organization has recognized the largely linear relationship between body weight and these risk factors when BMI increases from 20 to $30 \mathrm{~kg} / \mathrm{m}^{2}$, and has identified $30 \mathrm{~kg} / \mathrm{m}^{2}$ as the threshold above which risk for CHD is high. ${ }^{12}$ This has led to the widespread use of BMI as a simple, cost-effective marker of obesity and CHD risk in able-bodied populations. $^{12,51}$ However, the relationship between BMI or body weight and CHD risk factors in the SCI population is variable. Zlotolow et $a l^{14}$ found no relationship between $\mathrm{BMI}$ and lipid levels in their study of 28 veterans with paraplegia, nor did Bauman et $a l^{42}$ find a significant correlation between body weight and insulin sensitivity in 100 veterans with SCI. BMI in other studies of persons with SCI has been found to explain 5-29\% of the variance in lipid parameters. ${ }^{16-18}$

The variable relationship between BMI and CHD risk factors in the SCI population may be due to the potential measurement error associated with BMI, the insensitivity of body weight in distinguishing fat mass from fat-free mass, and the lack of information conveyed by BMI regarding body fat distribution. Abdominal obesity, specifically visceral adipose tissue, is an independent risk factor for CHD in able-bodied populations. Visceral adipose tissue is intra-abdominal fat bound by the parietal peritoneum, and is measured using computed tomography or magnetic resonance imaging. A visceral fat depot of $>130 \mathrm{~cm}^{2}$ is associated with significant proatherogenic changes in the plasma lipoprotein-lipid profile as well as in indices of glucoseinsulin homeostasis. ${ }^{52}$ In his comprehensive review, Després $^{53}$ notes that abdominal visceral adipose tissue is characterized by very active lipolysis. Since high freefatty acid levels have been shown to reduce the binding and uptake of insulin by hepatocytes, an enlarged visceral fat depot may expose the liver to high free-fatty acid levels, leading to a reduced hepatic extraction of 
insulin. Thus, visceral adipose tissue is associated with hyperinsulinemia, insulin resistance and glucose intolerance. Furthermore, the activity of lipoprotein lipase (a lipolytic enzyme which hydrolyzes triglycerides into lipoproteins) in skeletal muscle is negatively correlated with in vivo insulin resistance, which could contribute to the impaired catabolism of triglyceride-rich lipoproteins observed in insulin-resistant subjects. The hypertriglyceridemia of abdominal obesity is associated with triglyceride enrichment of LDL and HDL cholesterols, leading to the production of dense LDL cholesterol (with a reduced affinity for the cellular LDL receptor), increased levels of apolipoprotein B and reduced plasma HDL cholesterol levels. Thus, visceral adipose tissue creates a metabolic environment consistent with increased risk of CHD. However, to the best of our knowledge, no study has measured visceral adipose tissue in persons with chronic SCI, despite the finding that total truncal fat mass is significantly greater in men with SCI versus age- and height-, weight- and/or BMImatched able-bodied men. 6,8

\section{Waist circumference: the missing link?}

Waist circumference may offer the clinician the most practical bedside measurement of visceral adipose tissue. A waist circumference $>100 \mathrm{~cm}$ has been reported to be a good surrogate for a visceral adipose depot $>130 \mathrm{~cm}^{2}$ in able-bodied men and women. ${ }^{54}$ Waist circumference has been shown in large epidemiological studies of ablebodied populations to be strongly, significantly and independently correlated with blood pressure, dyslipidemia, fasting plasma glucose, 2-h plasma glucose and/ or diabetes, even after adjusting for age and other confounding variables, and even among normal-weight subjects. ${ }^{49,55,56}$ Furthermore, waist circumference was found to correlate more strongly than BMI with three of four obesity-related risk factors (LDL cholesterol, blood pressure, glucose, but not HDL cholesterol) in over 9000 participants of the third National Health and Nutrition Examination Survey, ${ }^{50}$ similar to findings of other studies in the able-bodied literature. ${ }^{57-60}$

Waist circumference is measured in standing ablebodied adults using a measuring tape placed around the abdomen in a horizontal plane, with the subjects' arms hanging freely, after normal expiration. ${ }^{61}$ Exact location of the measuring tape continues to be debated. A recent study ${ }^{62}$ of 111 able-bodied males and females 7-83 years determined that waist circumference values measured at four sites (immediately below the lowest rib, at the narrowest waist, midpoint between the lowest rib and the iliac crest and immediately above the iliac crest) had equally high reproducibility and were almost equally associated with total body fat and trunk fat in each sex. The authors noted that of the 14 anatomical locations commonly reported in the literature, the narrowest waist is the most frequently recommended. In many subjects in their study, the narrowest waist was found to be at the lowest rib, a site the authors found easy to identify in most subjects, even in obese persons. The umbilicus may not be an appropriate landmark in obese persons because its position changes with increasing fat mass.

Three studies ${ }^{11,15,63}$ have measured waist circumference in subjects with chronic SCI. Jeon et $a l^{11}$ did not report values, nor was the method of obtaining waist circumference described. Maki et $a l^{63}$ measured waist circumference in 46 men with paraplegia and tetraplegia of $>6$ months duration. Measures were carried out in duplicate at the level of the umbilicus after normal expiration, with subjects supine. If values differed by $>1 \mathrm{~cm}$, a third measurement was taken and the results of the two or three trials were averaged. Weight was determined by wheelchair scale. Height was either selfreported or measured in a supine position using a metal measuring tape. Fat mass was determined using near infrared interactance. Waist circumference explained $15-34 \%$ of the variance in HDL cholesterol, $\log 10$ triglyceride as well as ratios of total:HDL cholesterols and LDL:HDL cholesterols, more so than BMI and percent fat mass (8-19 and $8-15 \%$, respectively). Only waist circumference was significantly associated with HDL cholesterol. While these findings may indicate waist circumference to be a better indicator of CHD risk than BMI or percent fat mass, they need to be interpreted with caution. Self-reported height may have introduced measurement error in the calculation of BMI; as well, near infrared interactance has not been validated in the SCI population. This may have obscured the relationships between BMI, fat mass and CHD risk. Nonetheless, waist circumference was strongly and significantly associated with CHD risk. Demirel et $\mathrm{al}^{15}$ measured waist circumference in 69 men and women with paraplegia and tetraplegia and 52 ageand sex-matched able-bodied controls. Measurements were made at the level of the umbilicus after normal expiration with subjects supine; measurement error was not reported. Waist circumference did not differ between the two groups (SCI: $84.8 \pm 10 \mathrm{~cm}$ versus able-bodied: $85.7 \pm 11 \mathrm{~cm}$, mean $\pm \mathrm{SD}$ ), but the authors did report higher glucose, uric acid, total and LDL cholesterols and lower HDL cholesterol, and higher ratios of total/ HDL cholesterols and LDL/HDL cholesterols in the subjects with SCI (all $P<0.001$ ). These proatherogenic changes may have been due to greater visceral versus subcutaneous adipose tissue in the SCI group, although this requires confirmation. Taken together, evidence from able-bodied populations suggests that waist circumference is strongly and independently associated, more so than BMI, with various CHD risk factors. Preliminary evidence in the SCI population supports an association between waist circumference and CHD risk factors. However, a number of issues pertaining to waist circumference have yet to be addressed in this population. These include (1) the accuracy and reliability of waist circumference as a surrogate measure of visceral adipose tissue, (2) identification of the most appropriate measurement site, (3) examination of the effects of positioning (supine, sitting, standing) and (4) effects of potential confounding variables unique to this popula- 
tion, including spasticity, loss of muscle tone and abdominal distension.

\section{Conclusion}

In the SCI population, BMI may be prone to measurement error, does not adequately discriminate between the obese versus nonobese, explains less of the variance in measured percent fat mass than in able-bodied populations, and is inconsistently associated to CHD risk factors. However, BMI continues to be widely reported in the spinal cord literature. We recommend that future research efforts determine SCI-specific BMI obesity classifications.

Waist circumference, a reproducible surrogate measure of visceral abdominal adiposity, is associated with many CHD risk factors, more so than BMI, in ablebodied populations. Preliminary evidence supports a relationship between waist circumference and CHD risk factors in the SCI population. We recommend that accuracy and reliability of waist circumference as a surrogate measure of visceral adipose tissue, and the relationship between waist circumference and CHD risk factors, be determined in men and women with longstanding paraplegia and tetraplegia.

\section{References}

1 Bray GA. Contemporary Diagnosis and Management of Obesity. Newton, PA 1998.

2 Lohman T, Going S. Assessment of body composition and energy balance. In Lamb D, Murray R (eds). Perspectives in Exercise Science and Sports Medicine. Cooper Publishing Group: Carmel 1998 pp 61-105.

3 Pi-Sunyer FX. Obesity: criteria and classification. Proc Nutr Soc 2000; 59: 505-509.

4 Monroe MB et al. Lower daily energy expenditure as measured by a respiratory chamber in subjects with spinal cord injury compared with control subjects. Am J Clin Nutr 1998; 68: 1223-1227.

5 Spungen AM et al. Factors influencing body composition in persons with spinal cord injury: a cross-sectional study. J Appl Physiol 2003; 95: 2398-2407.

6 Jones LM, Legge M, Goulding A. Healthy body mass index values often underestimate body fat in men with spinal cord injury. Arch Phys Med Rehabil 2003; 84: 1068-1071.

7 Buchholz AC, McGillivray CF, Pencharz PB. Differences in resting metabolic rate between paraplegic and ablebodied subjects are explained by differences in body composition. Am J Clin Nutr 2003; 77: 371-378.

8 Maggioni $\mathrm{M}$ et al. Body composition assessment in spinal cord injury subjects. Acta Diabetol 2003; 40(Suppl 1): S183-S186.

9 Modlesky CM et al. Assessment of skeletal muscle mass in men with spinal cord injury using dual-energy X-ray absorptiometry and magnetic resonance imaging. $J$ Appl Physiol 2004; 96: 561-565.

10 Desport JC et al. Total body water and percentage fat mass measurements using bioelectrical impedance analysis and anthropometry in spinal cord-injured patients. Clin Nutr 2000; 19: 185-190.
11 Jeon JY et al. Intact sympathetic nervous system is required for leptin effects on resting metabolic rate in people with spinal cord injury. $J$ Clin Endocrinol Metab 2003; 88: 402-407.

12 World Health Organization. Obesity: preventing and managing the global epidemic. Report of WHO Consultation. Geneva: World Health Organization 2000.

13 Buchholz AC, McGillivray CF, Pencharz PB. Physical activity levels are low in free-living adults with chronic paraplegia. Obes Res 2003; 11: 563-570.

14 Zlotolow SP, Levy E, Bauman WA. The serum lipoprotein profile in veterans with paraplegia: the relationship to nutritional factors and body mass index. J Am Paraplegia Soc 1992; 15: 158-162.

15 Demirel S et al. Risk factors for coronary heart disease in patients with spinal cord injury in Turkey. Spinal Cord 2001; 39: 134-138.

16 Janssen TW et al. Coronary heart disease risk indicators, aerobic power, and physical activity in men with spinal cord injuries. Arch Phys Med Rehabil 1997; 78: 697-705.

17 Dallmeijer AJ, Hopman MT, van der Woude LH. Lipid, lipoprotein, and apolipoprotein profiles in active and sedentary men with tetraplegia. Arch Phys Med Rehabil 1997; 78: 1173-1176.

18 Bauman WA et al. The effect of residual neurological deficit on serum lipoproteins in individuals with chronic spinal cord injury. Spinal Cord 1998; 36: 13-17.

19 Frisancho AR. Methods and materials. Anthropometric standards for the assessment of growth and nutritional status. The University of Michigan Press: Ann Arbor 1990 pp 9-30.

20 Garshick E et al. Assessment of stature in spinal cord injury. J Spinal Cord Med 1997; 20: 36-42.

21 Jones LM, Legge M, Goulding A. Intensive exercise may preserve bone mass of the upper limbs in spinal cord injured males but does not retard demineralisation of the lower body. Spinal Cord 2002; 40: 230-235.

22 Buchholz AC, McGillivray CF, Pencharz PB. The use of bioelectric impedance analysis to measure fluid compartments in subjects with chronic paraplegia. Arch Phys Med Rehabil 2003; 84: 854-861.

23 Spungen AM et al. Soft tissue body composition differences in monozygotic twins discordant for spinal cord injury. J Appl Physiol 2000; 88: 1310-1315.

24 Israel RG et al. Sensitivity and specificity of current methods for classifying morbid obesity. Diabetes Res Clin Pract 1990; 10(Suppl 1): S145-S147.

25 Yao $\mathrm{M}$ et al. Field methods for body composition assessment are valid in healthy chinese adults. J Nutr 2002; 132: 310-317.

26 Piers LS et al. Indirect estimates of body composition are useful for groups but unreliable in individuals. Int $J$ Obes Relat Metab Disord 2000; 24: 1145-1152.

27 Zhu S et al. Associations of body mass index and anthropometric indicators of fat mass and fat free mass with all-cause mortality among women in the first and second National Health and Nutrition Examination Surveys follow-up studies. Ann Epidemiol 2003; 13: 286-293.

28 Luke A et al. Relation between body mass index and body fat in black population samples from Nigeria, Jamaica, and the United States. Am J Epidemiol 1997; 145: 620-628.

29 Gallagher D et al. Healthy percentage body fat ranges: an approach for developing guidelines based on body mass index. Am J Clin Nutr 2000; 72: 694-701. 
30 Zhong YG, Levy E, Bauman WA. The relationships among serum uric acid, plasma insulin, and serum lipoprotein levels in subjects with spinal cord injury. Horm Metab Res 1995; 27: 283-286.

31 Hartkopp A et al. Survival and cause of death after traumatic spinal cord injury. A long-term epidemiological survey from Denmark. Spinal Cord 1997; 35: 76-85.

32 DeVivo MJ, Black KJ, Stover SL. Causes of death during the first 12 years after spinal cord injury. Arch Phys Med Rehabil 1993; 74: 248-254.

33 Whiteneck GG et al. Mortality, morbidity, and psychosocial outcomes of persons spinal cord injured more than 20 years ago. Paraplegia 1992; 30: 617-630.

34 Yekutiel $\mathrm{M}$ et al. The prevalence of hypertension, ischaemic heart disease and diabetes in traumatic spinal cord injured patients and amputees. Paraplegia 1989; 27: $58-62$.

35 Bauman WA et al. Coronary artery disease: metabolic risk factors and latent disease in individuals with paraplegia. Mt Sinai J Med 1992; 59: 163-168.

36 Shetty KR et al. Lipid and lipoprotein abnormalities in young quadriplegic men. Am J Med Sci 1992; 303: 213-216.

37 Schmid A et al. Lipoproteins and free plasma catecholamines in spinal cord injured men with different injury levels. Clin Physiol 2000; 20: 304-310.

$38 \mathrm{Karlsson} \mathrm{AK}$. Insulin resistance and sympathetic function in high spinal cord injury. Spinal Cord 1999; 37: 494-500.

39 Bauman WA et al. Depressed serum high density lipoprotein cholesterol levels in veterans with spinal cord injury. Paraplegia 1992; 30: 697-703.

40 Krum $\mathrm{H}$ et al. Risk factors for cardiovascular disease in chronic spinal cord injury patients. Paraplegia 1992; 30: 381-388.

41 Bauman WA et al. The effect of residual neurological deficit on oral glucose tolerance in persons with chronic spinal cord injury. Spinal Cord 1999; 37: 765-771.

42 Bauman WA, Spungen AM. Disorders of carbohydrate and lipid metabolism in veterans with paraplegia or quadriplegia: a model of premature aging. Metabolism 1994; 43: 749-756.

43 Duckworth WC et al. Glucose intolerance due to insulin resistance in patients with spinal cord injuries. Diabetes 1980; 29: 906-910.

44 Duckworth WC, Jallepalli P, Solomon SS. Glucose intolerance in spinal cord injury. Arch Phys Med Rehabil 1983; 64: 107-110.

45 Tharion $\mathrm{G}$ et al. Glucose intolerance and dyslipidaemias in persons with paraplegia and tetraplegia in south India. Spinal Cord 1998; 36: 228-230.

46 Sabharwal S. Cardiovascular dysfunction in spinal cord disorders. In Lin VW (ed) Spinal Cord Medicine. Demos Medical Publishing, Inc.: New York 2003, pp 179-192.

47 Lean ME. Pathophysiology of obesity. Proc Nutr Soc 2000; 59: 331-336.
48 Sharma AM. Obesity and cardiovascular risk. Growth Horm IGF Res 2003; 13(Suppl A): S10-S17.

49 Dalton $\mathrm{M}$ et al. Waist circumference, waist-hip ratio and body mass index and their correlation with cardiovascular disease risk factors in Australian adults. J Intern Med 2003; 254: 555-563.

$50 \mathrm{Zhu} \mathrm{S}$ et al. Waist circumference and obesity-associated risk factors among whites in the third National Health and Nutrition Examination Survey: clinical action thresholds. Am J Clin Nutr 2002; 76: 743-749.

51 National Institutes of Health NHLaBI. Clinical Guidelines on the Identification, Evaluation, and Treatment of Overweight and Obesity in Adults - The Evidence Report. National Institutes of Health. Obes Res 1998; 6(Suppl 2): 51S-209S.

52 Despres JP, Lamarche B. Effects of diet and physical activity on adiposity and body fat distribution: implications for the prevention of cardiovascular disease. Nutr Res Rev 1993; 6: 137-159.

53 Despres JP. Abdominal obesity as important component of insulin-resistance syndrome. Nutrition 1993; 9: 452-459.

54 Lemieux $\mathrm{S}$ et al. A single threshold value of waist girth identifies normal-weight and overweight subjects with excess visceral adipose tissue. Am J Clin Nutr 1996; 64: 685-693.

55 Chan JM et al. Obesity, fat distribution, and weight gain as risk factors for clinical diabetes in men. Diabet Care 1994; 17: 961-969.

56 Janssen I, Katzmarzyk PT, Ross R. Body mass index, waist circumference, and health risk: evidence in support of current National Institutes of Health guidelines. Arch Intern Med 2002; 162: 2074-2079.

57 Baik I et al. Adiposity and mortality in men. Am J Epidemiol 2000; 152: 264-271.

58 Reeder BA et al. The association of cardiovascular disease risk factors with abdominal obesity in Canada. Canadian Heart Health Surveys Research Group. Can Med Assoc J 1997; 157(Suppl 1): S39-S45.

59 Lofgren I et al. Waist circumference is a better predictor than body mass index of coronary heart disease risk in overweight premenopausal women. J Nutr 2004; 134: 1071-1076.

60 Janssen I, Katzmarzyk PT, Ross R. Waist circumference and not body mass index explains obesity-related health risk. Am J Clin Nutr 2004; 79: 379-384.

61 Standardization of anthropometric measurements. In Lohman T, Roche A, Martorel R (eds). The Airlie (VA) Consensus Conference. Human Kinetics: Champaign, IL 1988, pp 39-80.

62 Wang $\mathrm{J}$ et al. Comparisons of waist circumferences measured at 4 sites. Am J Clin Nutr 2003; 77: 379-384.

63 Maki $\mathrm{KC}$ et al. Associations between serum lipids and indicators of adiposity in men with spinal cord injury. Paraplegia 1995; 33: 102-109. 